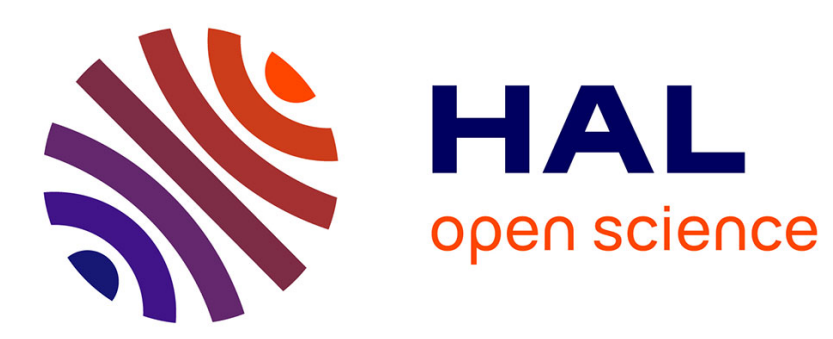

\title{
Reducing nitrate leaching after winter oilseed rape and peas in mild and cold winters
}

\author{
Engström, Stenberg, Aronsson, Lindén
}

\section{To cite this version:}

Engström, Stenberg, Aronsson, Lindén. Reducing nitrate leaching after winter oilseed rape and peas in mild and cold winters. Agronomy for Sustainable Development, 2011, 31 (2), pp.337-347. 10.1051/agro/2010035 . hal-00930464

\section{HAL Id: hal-00930464 \\ https://hal.science/hal-00930464}

Submitted on 1 Jan 2011

HAL is a multi-disciplinary open access archive for the deposit and dissemination of scientific research documents, whether they are published or not. The documents may come from teaching and research institutions in France or abroad, or from public or private research centers.
L'archive ouverte pluridisciplinaire HAL, est destinée au dépôt et à la diffusion de documents scientifiques de niveau recherche, publiés ou non, émanant des établissements d'enseignement et de recherche français ou étrangers, des laboratoires publics ou privés. 


\title{
Research article
}

\section{Reducing nitrate leaching after winter oilseed rape and peas in mild and cold winters}

\author{
Lena ENGSTRÖM ${ }^{1 *}$, Maria STENBERG ${ }^{1}$, Helena ARONSSON $^{2}$, Börje LINDÉN $^{1}$ \\ ${ }^{1}$ Swedish University of Agricultural Sciences, Department of Soil and Environmental Sciences, PO Box 234, SE-532 23 Skara, Sweden \\ ${ }^{2}$ Swedish University of Agricultural Sciences, Department of Soil and Environmental Sciences, PO Box 234, SE-532 23 Skara1 (Uppsala2), Sweden
}

(Accepted 9 June 2010) (Published online: 24 September 2010)

\begin{abstract}
Nitrate leaching after winter oilseed rape and peas has not been studied at the most northern limits of oilseed rape cultivation where winters vary between being mild, with continuous drainage, and cold, with periods of frozen soil. Here, we studied the effect of $\mathrm{N}$ fertilisation to oilseed rape, catch crops after oilseed rape and peas and dired drilling of winter wheat after oilseed rape on N leaching in south-west Sweden. Nitrate leaching was determined in two field experiments, dated 2004-2006 and 2005-2007, respectively, on a sandy loam. Our results show that under oilseed rape nitrate leaching was low, at $16-23 \mathrm{~kg} \mathrm{~N} \mathrm{ha}^{-1}$, in a mild winter with drainage from October to March. In the subsequent mild winter nitrate leaching under wheat was higher, amounting to $35-94 \mathrm{~kg} \mathrm{~N} \mathrm{ha}^{-1}$. Nitrate leaching levels were similar, 32-58 $\mathrm{kg} \mathrm{N}^{-1}$, for all crops in a cold winter with a long-lasting snow cover and main drainage occurring after snowmelt in March and April. Application of fertiliser $\mathrm{N}$ to oilseed rape at the optimum $\mathrm{N}$ rate, rather than $50 \mathrm{~kg} \mathrm{~N}^{-1}$ above optimum, reduced leaching in a following winter wheat crop by 25 and $27 \mathrm{~kg} \mathrm{~N} \mathrm{ha}^{-1}$ in a cold and a mild winter, respectively. Spring undersowing of perennial ryegrass as a catch crop reduced leaching by $12 \mathrm{~kg} \mathrm{~N} \mathrm{ha}^{-1}$ after optimally fertilised oilseed rape in a mild winter, despite only growing until mid-September when winter wheat was sown. An undersown catch crop of peas, then grown until November, reduced leaching by $15 \mathrm{~kg} \mathrm{~N} \mathrm{ha}^{-1}$. Direct drilling of winter wheat after oilseed rape had no effect. These findings show that there are risks of enhanced leaching in early spring after a cold winter with a snow cover and superficially frozen soil. Optimising the spring $\mathrm{N}$ rate for oilseed rape was the most effective measure to decrease leaching in both mild and cold winters, and this effect was improved by an undersown catch crop in a mild winter.
\end{abstract}

optimum $\mathrm{N}$ rate / ryegrass catch crop / direct drilling / soil mineral $\mathrm{N} / \mathrm{N}$ uptake / drainage

\section{INTRODUCTION}

Winter oilseed rape (WOR) and peas as a preceding crop to winter wheat have been reported to increase yield and soil nitrogen (N) supply (Engström and Lindén, 2009). However, the amounts of accumulated soil mineral $\mathrm{N}$ at harvest and in late autumn (November) after WOR and peas are often higher than after cereals (Jensen and Haahr, 1990; Sieling et al., 1999; Ryan et al., 2006). Seedbed preparation for the following winter wheat crop can further stimulate soil $\mathrm{N}$ mineralisation. Therefore, $\mathrm{N}$ leaching is often increased during the following autumn and winter if the amount of drainage is high and crop $\mathrm{N}$ uptake is low (Christen et al., 1992; Sieling et al., 1999; Knudsen et al., 2002), which is usually the case in northern Europe.

* Corresponding author: lena.engstrom@mark.slu.se
WOR has a higher demand for available $\mathrm{N}$ at establishment and in early spring than cereal crops (Razoux Schultz, 1972). In Sweden, the general recommendation for $\mathrm{N}$ fertilisation of WOR is $30-60 \mathrm{~kg} \mathrm{~N} \mathrm{ha}^{-1}$ at establishment when the previous crop is cereals. A split application of $130-170 \mathrm{~kg} \mathrm{~N} \mathrm{ha}^{-1}$ in the spring, half at start of growth and half at stem elongation, is recommended for an expected yield of 2.5-4.5 tons ha ${ }^{-1}$. In Sweden, where winter oilseed rape is usually grown after a cereal crop, soil $\mathrm{N}$ mineralisation during autumn is not as high as in more southern countries due to a shorter and cooler autumn. This may explain why yield increases have been obtained with 30 and $60 \mathrm{~kg} \mathrm{~N} \mathrm{ha}^{-1}$ applied at sowing of winter oilseed rape under Swedish conditions (Biärsjö and Nilsson, 2007). The $\mathrm{N}$ requirement of peas is mainly met by $\mathrm{N}_{2}$ fixation and can amount to $240 \mathrm{~kg} \mathrm{~N} \mathrm{ha}^{-1}$ (Jensen, 1987).

Soil tillage in early autumn to incorporate crop residues, kill weeds and loosen the soil before establishing a new crop has been shown to increase mineralisation of soil N (Wallgren 
Table I. Crops and $\mathrm{N}$ rates in treatments A-I.

\begin{tabular}{|c|c|c|c|c|c|c|c|c|c|}
\hline Treatment & $\mathrm{A}$ & $\mathrm{B}$ & $\mathrm{C}$ & $\mathrm{D}$ & $\mathrm{E}$ & $\mathrm{F}$ & $\mathrm{G}$ & $\mathrm{H}$ & I \\
\hline Crop1 & Oat & Pea & Pea $+c c$ & $\mathrm{WOR}+\mathrm{cc}$ & WOR & WOR & WOR & WOR & WOR \\
\hline $\mathrm{N}$ rate in spring $\left(\mathrm{kg} \mathrm{ha}^{-1}\right)$ & 100 & 0 & 0 & 150 & 0 & 100 & 150 & 200 & 150 \\
\hline
\end{tabular}

Legend: WOR: winter oilseed rape; cc: catch crop; dd: direct drilling of winter wheat.

and Lindén, 1994; Stenberg et al., 1999). Reduced and delayed tillage in autumn before establishing a crop can keep soil mineral $\mathrm{N}$ at a low level in late autumn and thus minimise N leaching (Davies et al., 1996; Djurhuus and Olsen, 1997; Stenberg et al., 1999). A positive correlation has been found between excessive $\mathrm{N}$ fertilisation to oilseed rape and $\mathrm{N}$ leaching during the subsequent autumn and winter (Shepard and Sylvester-Bradley, 1996; Sieling et al., 1997; Henke et al., 2008). In Sweden, an exponential relationship has been found between increased mineral $\mathrm{N}$ fertilisation to cereal crops and increased N leaching (Bergström and Brink, 1986), but this has not been investigated for WOR. Catch crops such as perennial ryegrass (Lolium perenne L.) have been shown to counteract the increased risk of leaching after cereals when grown until late autumn and spring (Møller Hansen and Djurhuus, 1997; Torstensson and Aronsson, 2000; Constantin et al., 2010). There is a lack of studies on catch crops undersown in WOR or peas and grown until establishment of a winter cereal.

The effects of management strategies to reduce $\mathrm{N}$ leaching after WOR and peas have mainly been investigated separately and under mild winter conditions, e.g. southerly maritime regions of Sweden. In the most northerly regions for growing WOR (e.g. Västergötland) winters vary between being mild, with more or less continuous drainage all winter, and cold, with long or short periods of frozen soil and varying snow cover. Cold winters, with longer periods of deeply frozen soil preventing drainage (Gustafson, 1983), are generally considered to cause less $\mathrm{N}$ leaching than mild winters. The period between harvest of WOR and sowing of winter wheat is short at the northern limit of WOR cultivation and will thus affect the impact of a catch crop on $\mathrm{N}$ leaching. Therefore, a catch crop undersown in spring should be more efficient than one sown after harvest, but this needs to be further investigated. To determine strategies or recommendations for reducing $\mathrm{N}$ leaching after WOR and peas grown in their most northerly cultivation regions, management strategies need to be evaluated at a fixed site and under the mild and cold winter weather conditions occurring in these regions.

The aim of the present study was to compare the effect of mild and cold winter conditions in Västergötland on N leaching when growing WOR, peas and oats followed by winter wheat. A second aim was to compare management strategies for reducing leaching in the following winter wheat under mild and cold winter conditions. The strategies compared were: (1) optimal spring $\mathrm{N}$ fertilisation of WOR; (2) a catch crop, undersown in WOR and grown until mid-September followed by sowing of winter wheat, or undersown in peas and grown until November, and (3) direct drilling of winter wheat after WOR.

\section{MATERIALS AND METHODS}

\subsection{Site and weather conditions}

Field experiments were carried out at Götala experimental farm in Västergötland, south-west Sweden (58 $22 \mathrm{~N}$, $13^{\circ} 29 \mathrm{E}$ ), on a sandy loam soil (14\% clay, $22 \%$ silt and $64 \%$ sand) with $\mathrm{pH}_{\mathrm{H}_{2} \mathrm{O}} 6.4$ and $2.8 \%$ soil organic matter $(1.6 \% \mathrm{C}$ and $0.14 \% \mathrm{~N}$ ) in the $0-30 \mathrm{~cm}$ layer. The subsoil had a larger fraction of coarse sand in the 30-60 cm (12\% clay, $17 \%$ silt and $71 \%$ sand) and the $60-90 \mathrm{~cm}$ layers (12.5\% clay, $20 \%$ silt and $67 \%$ sand) and $2.5 \%$ soil organic matter. The previous crop was winter wheat (Triticum aestivum L.). The experimental site had a history of regular application of farmyard manure (dairy cow slurry), although none had been applied since 2001. Air temperature and precipitation data were obtained from Lanna research station $\left(58^{\circ} 21 \mathrm{~N}, 13^{\circ} 08 \mathrm{E}\right)$ (Tab. I). The thirty-year average annual precipitation (1961-1990) at Lanna research station is $560 \mathrm{~mm}$, with $375 \mathrm{~mm}$ falling during AprilSeptember and $246 \mathrm{~mm}$ during October-March.

\subsection{Treatments and experimental design}

Two field experiments, with WOR, peas and oats grown prior to wheat, were carried out during 2004-2006 (experiment 1) and 2005-2007 (experiment 2) with nine treatments and three replicates in a complete randomised block design (Fig. 1, Tab. I). In six of the nine treatments (D-I), WOR (Brassica napus L.) was sown in $6 \mathrm{~m} \times 30 \mathrm{~m}$ plots on 18 August 2004 in experiment 1 (cv. Kronos, $4 \mathrm{~kg} \mathrm{ha}^{-1}$ ) and on 25 August 2005 in experiment 2 (cv. Calypso, $6.5 \mathrm{~kg} \mathrm{ha}^{-1}$ ). Two tine cultivations were followed by mouldboard ploughing and harrowing twice before sowing of WOR. At this time treatments A-C were also tine-cultivated (by accident not in experiment 2 ) followed by mouldboard ploughing in the spring before sowing of oats and peas. In order to study winter oilseed rape grown according to general practices, recommended $\mathrm{N}$ rates of 30 and $60 \mathrm{~kg} \mathrm{~N} \mathrm{ha}^{-1}$ at sowing were used. All plots were fertilised with $50 \mathrm{~kg} \mathrm{ha}^{-1}$ phosphorus (P), $60 \mathrm{~kg} \mathrm{ha}^{-1}$ potassium (K) and $15 \mathrm{~kg} \mathrm{ha}^{-1}$ sulphur (S) before sowing. In the following spring, treatment A was sown with spring oats (Avena sativa 


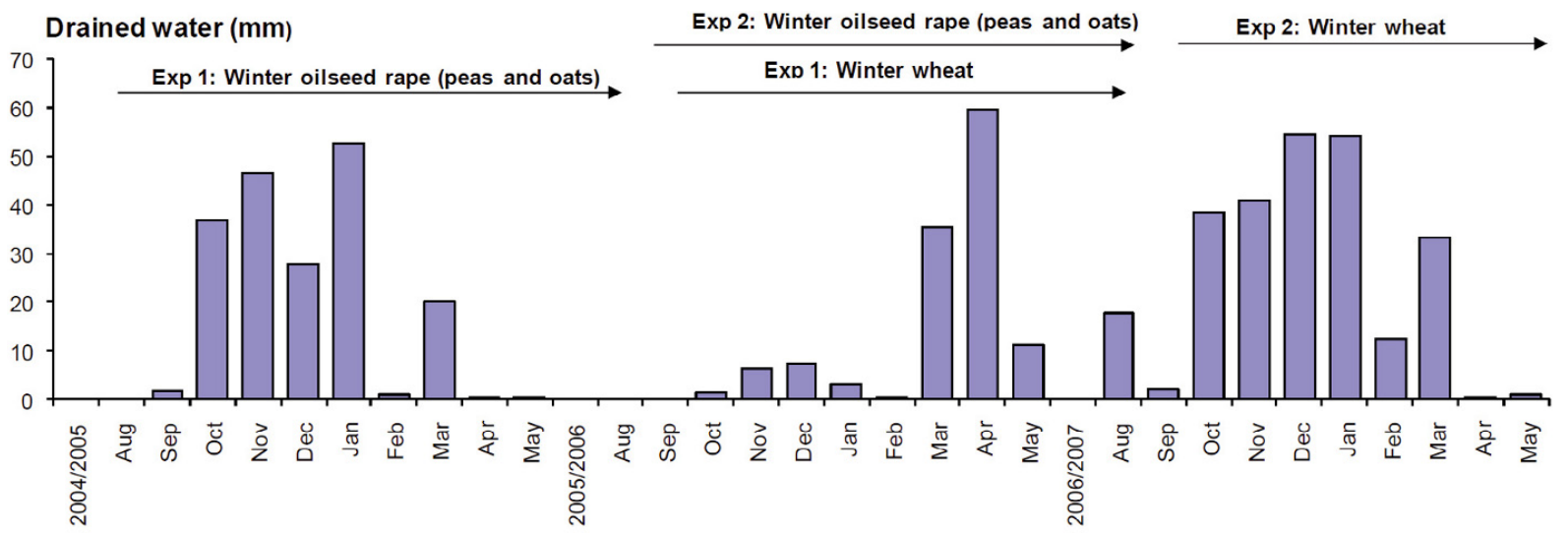

Figure 1. Drainage volume on a sandy soil in Fotegården in August-May 2004/2005 (214 mm), 2005/2006 (130 mm) and $2006 / 2007$ (238 mm), i.e. the periods when the two field experiments were performed at Götala.

L. cv. Freddy) and treatments B and C with field peas (Pisum sativum L., cv. Brutus and Faust) on 13 April 2005 and 24 April 2006. Perennial ryegrass (Lolium perenne L.) was undersown $\left(8 \mathrm{~kg} \mathrm{ha}^{-1}\right)$ as a catch crop in WOR (D) on 4 and 24 April and in peas (C) on 6 May and 24 April in experiments 1 and 2 , respectively.

After harvest of WOR, peas and oats, winter wheat (cv. Harnesk and Olivin) was established in all treatments except C. All treatments except $\mathrm{C}$ and I were mouldboard-ploughed on 15 and 20 September in experiments 1 and 2, respectively. Winter wheat was direct-drilled in treatment I at the time of sowing in the other treatments (19 and 18 September in experiments 1 and 2, respectively). Treatment $\mathrm{C}$ was ploughed in autumn ( 1 and 2 November) and then spring wheat was sown in the following year (cv. Triso, 24 April 2006 and cv. Vinjett, 30 March 2007). Each plot was divided into two randomised subplots fertilised with 0 or $100 \mathrm{~kg} \mathrm{~N} \mathrm{ha}^{-1}$, respectively. Herbicides and insecticides were applied to all crops according to regional recommendations.

\subsection{Nitrate leaching measurements}

Nitrate leaching $\left(\mathrm{NO}_{3}-\mathrm{N}\right)$ was determined plot-wise by sampling soil water with ceramic suction cups (Djurhuus, 1990) installed in triplicate at $80 \mathrm{~cm}$ depth in the main plots, where wheat was fertilised with $100 \mathrm{~kg} \mathrm{~N} \mathrm{ha}^{-1}$. Sampling was carried out every second week during periods with drainage, usually September-April, by applying a suction of $60-70 \mathrm{kPa}$ for $24 \mathrm{~h}$ before the sampling was performed. Nitrate concentrations in soil water samples from all suction cups were analysed by flow injection analysis (Tecator AB, Höganäs, Sweden) according to the colorimetric $\mathrm{Cd}$ reduction method (APHA, 1985). For estimations of drainage flow, data were taken from a long-term field leaching experiment on a sandy loam soil (Fotegården $58^{\circ} 28 \mathrm{~N}, 13^{\circ} 21 \mathrm{E}$, approx. $20 \mathrm{~km}$ from Götala experimental farm) where water flow was measured and recorded continuously. The drainage measurements therefore represented the mean drainage from soil cropped with cereals, with and without an undersown catch crop. This approach did not consider possible differences in drainage amounts due to differences in evapotranspiration during autumn in the different treatments, although such differences probably occurred to some extent. In similar conditions, undersown ryegrass catch crops were reported to result in $0-7 \%$ less drainage than from soil ploughed in autumn (Hansen and Djurhuus, 1997; Torstensson and Aronsson, 2000). Leaching loads of nitrate- $\mathrm{N}$ were calculated by multiplying the concentrations in the samples by the amounts of daily drainage. In order to achieve daily values of concentrations, linear interpolation was used between the measured values.

\subsection{Measurement of soil mineral $\mathbf{N}$}

Soil mineral $\mathrm{N}\left(\mathrm{NO}_{3}-\mathrm{N}\right.$ and $\left.\mathrm{NH}_{4}-\mathrm{N}\right)$ in the $0-90 \mathrm{~cm}$ soil layer was determined at harvest of the first year's crops, in late autumn, in the next year, in early spring and at maturity of the following wheat crops. Soil samples were taken plot-wise at 0-30, 30-60 and 60-90 cm depth and stored frozen. In each plot, 8 randomly distributed soil cores were taken from the 0-30 cm layer and 6 cores within the 30-60 and 60-90 cm layers. These samples were homogenised, frozen and a subsample of $30 \mathrm{~g}$ of soil was extracted with $100 \mathrm{~mL} 2 \mathrm{M} \mathrm{KCl}$ (Mulvaney, 1996). Analyses were then carried out using a colorimetric method on TRAACS 800 equipment.

\subsection{Crop $\mathrm{N}$ uptake and yield}

Crop $\mathrm{N}$ uptake was quantified by sampling aboveground plant material for analyses of total dry matter (DM) and $\mathrm{N}$ content. WOR was sampled at the beginning of November, at the end of March and at ripening in August. Catch crops were sampled at the time of ripening of the respective main crop and before ploughing in autumn. Wheat crops were sampled at ripening. Aboveground crop material was cut at the 
Table II. Mean air temperature $\left({ }^{\circ} \mathrm{C}\right.$ ) and monthly precipitation (mm) during the growing period (July-June) 2004/2005-2006/2007 and 30-year mean (1961-1990) at Lanna research station, Lidköping, Sweden.

\begin{tabular}{|c|c|c|c|c|c|c|c|c|c|c|c|c|c|}
\hline & Jul & Aug & Sep & Oct & Nov & Dec & Jan & Feb & Mar & Apr & May & Jun & Total \\
\hline Mean air temperature $\left({ }^{\circ} \mathrm{C}\right) 2004 / 2005$ & 14.4 & 17.0 & 12.0 & 6.8 & 1.1 & 2.1 & 1.0 & -1.7 & -1.4 & 6.0 & 9.9 & 12.8 & \\
\hline $2005 / 2006$ & 16.6 & 15.6 & 11.6 & 7.8 & 4.8 & -0.1 & -4.3 & -3.8 & -5.9 & 4.9 & 11.1 & 15.2 & \\
\hline $2006 / 2007$ & 18.9 & 16.8 & 14.8 & 9.9 & 5.3 & 4.5 & 1.3 & -1.6 & 4.1 & 7.5 & 10.3 & 15.5 & \\
\hline $1961-1990$ & 15.7 & 14.9 & 11 & 7.1 & 2.1 & -1.4 & -3.1 & -3.4 & -0.3 & 4.4 & 10.6 & 14.7 & \\
\hline \multicolumn{14}{|l|}{ Precipitation (mm) } \\
\hline $2004 / 2005$ & 126 & 61 & 55 & 62 & 58 & 18 & 37 & 14 & 18 & 23 & 56 & 96 & 620 \\
\hline $2005 / 2006$ & 104 & 47 & 14 & 56 & 40 & 18 & 21 & 23 & 29 & 49 & 62 & 35 & 500 \\
\hline $2006 / 2007$ & 33 & 96 & 23 & 101 & 49 & 67 & 80 & 19 & 48 & 26 & 63 & 95 & 700 \\
\hline $1961-1990$ & 63 & 62 & 65 & 61 & 56 & 39 & 37 & 24 & 29 & 30 & 41 & 51 & 558 \\
\hline
\end{tabular}

soil surface in two $0.25-\mathrm{m}^{2}$ areas in each plot. Each subplot for crop sampling was marked with a metal frame $(50 \mathrm{~cm} \times$ $50 \mathrm{~cm}$ ) which was placed randomly within the plot covering 4 seedrows, with a row spacing of $12.5 \mathrm{~cm}$ and with a minimum distance of $0.5 \mathrm{~m}$ to the plot border. Crop samples were dried at $55{ }^{\circ} \mathrm{C}$ for $24 \mathrm{~h}$. Total $\mathrm{N}$ content was generally determined plot-wise by LECO analysis $\left(\right.$ LECO $^{\circledR}$ CNS-2000, carbon, nitrogen and sulphur analyser).

Yield of WOR, peas and oats was determined by combineharvesting a $22-\mathrm{m}^{2}$ area of each plot and analysing portions of a $1000-\mathrm{g}$ subsample of grain for total DM, $\mathrm{N}$ and oil content. Wheat yield was determined for all treatments by combineharvesting $20 \mathrm{~m}^{2}$ in each plot fertilised with 0 and $100 \mathrm{~kg} \mathrm{~N}$ $\mathrm{ha}^{-2}$ and analysing portions of a $1000-\mathrm{g}$ subsample for total $\mathrm{DM}$ and $\mathrm{N}$ content. The $\mathrm{N}$ content in wheat, oats and peas was analysed on a Near-Infrared Transmittance detector (NIT, Infratech 1240) and that in oilseed rape seeds on a Dumas elemental analyser.

\subsection{Statistics and calculations}

Analysis of variance was carried out on data using the GLM procedure in MINITAB (Version 15, Minitab Inc., USA). Significant differences between treatments were identified using Tukey's studentised range test at $P<0.05$. Explorative data analysis was performed with principal component analysis (PCA; Wold et al., 1987) using the Unscrambler 9.8 software (Camo ASA, Oslo, Norway, www.camo.com). The variable structures were studied in loading plots which reveal linear variable to variable and variable to component relationships. Similarly, sample structures were studied in score plots. Variables were centred and scaled to unit variance before analysis.

Economic optimum $\mathrm{N}$ fertilisation rate in spring was calculated for WOR using a cubical polynomial function to describe the yield response to $\mathrm{N}$ fertilisation $(\mathrm{y}=$ yield and $\mathrm{x}=\mathrm{N}$ rate). This was done by identifying the points where the slope of the function was equivalent to the price ratio of seed to fertiliser, which was estimated as 5:1 from current Swedish prices (fertiliser $\mathrm{N}=15 \mathrm{SEK} \mathrm{kg}^{-1}$ and oilseed rape seeds $=3 \mathrm{SEK} \mathrm{kg}^{-1}$ ). Different $\mathrm{N}$ rates at sowing had the same effect on yield and were therefore not included. Payment for oil content was not considered.

\section{RESULTS AND DISCUSSION}

\subsection{Weather conditions and drainage}

In the first year of the experiment (2004/2005) and the third (2006/2007), the autumn and winter were milder than the 30-year mean, while rainfall was below and above the mean, respectively (Tab. II). The main drainage period was October-March (Fig. 1). Autumn and winter in the second year (2005/2006) had a dry period from 15 August to 19 October, followed by a colder winter than usual with belowfreezing temperatures and snow cover from 20 December to 27 March. The main drainage period was March-April. Due to the different weather conditions, two scenarios for $\mathrm{N}$ leaching during autumn and winter were obtained during growth of WOR (2004/2005 and 2005/2006) and during growth of winter wheat following WOR, peas and oats (2005/2006 and 2006/2007). These scenarios were: (1) a mild winter with a continuous main drainage period from October to March; and (2) a cold winter with main drainage following snowmelt at the end of the winter, in March and April (Fig. 1).

\subsection{Nitrate leaching during growth of winter oilseed rape}

During the mild winter of 2004/2005, there was significantly lower $\mathrm{N}$ leaching in experiment 1 in December, January and February in treatments where WOR had been established in August than in treatments cultivated in August and without a crop (Tab. III). For the whole drainage period there was also a tendency $(P=0.06)$ for $40 \%\left(14 \mathrm{~kg} \mathrm{~N} \mathrm{ha}^{-1}\right)$ lower $\mathrm{N}$ leaching in treatments with a WOR crop than without. During the cold winter of 2005/2006 there were no significant, corresponding differences in $\mathrm{N}$ leaching found between treatments in experiment 2. Both with and without a WOR crop, the $\mathrm{N}$ leaching in the cold winter was at the same level or higher than from soil without a crop in the mild winter.

In treatments with a growing WOR crop, the nitrate-N concentrations in soil water varied within the range $3.5-13.2 \mathrm{mg}$ $\mathrm{L}^{-1}$ during the mild winter (data not shown). The concentrations were generally below the European Union drinking water limit of $11.3 \mathrm{mg} \mathrm{L}^{-1}$. In the experimental plots without a crop, the concentrations were considerably higher, 3.4$39.8 \mathrm{mg}$ nitrate- $\mathrm{N} \mathrm{L}^{-1}$. In the cold winter, all treatments had 
Table III. Nitrate leaching ( $\mathrm{kg} \mathrm{NO}_{3}^{-} \mathrm{N} \mathrm{ha}^{-1}$ ) from July to June (only months with detectable leaching are shown) in experiments 1 and 2 in treatments with and without winter oilseed rape (WOR).

\begin{tabular}{|c|c|c|c|c|c|c|c|c|c|c|}
\hline Treatment & A & $\mathrm{B}$ & $\mathrm{C}$ & $\mathrm{D}$ & $\mathrm{E}$ & $\mathrm{F}$ & $\mathrm{G}$ & $\mathrm{H}$ & $\mathrm{I}$ & $P$-value \\
\hline \multicolumn{11}{|l|}{ Month } \\
\hline \multicolumn{11}{|c|}{ Experiment 1, 2004/2005 (mild winter) } \\
\hline Sep & 0.1 & 0.1 & 0.1 & 4.4 & 2.6 & 5.2 & 5.5 & 3.8 & 3.2 & n.s. \\
\hline Oct & 5.3 & 5.2 & 4.9 & 2.2 & 1.9 & 2.2 & 2.1 & 3.0 & 2.1 & n.s \\
\hline Nov & 13.6 & 10.8 & 10.4 & 3.9 & 5.3 & 4.1 & 3.9 & 5.0 & 3.7 & n.s \\
\hline Dec & $6.3^{\mathrm{ab}}$ & $6.6^{\mathrm{ab}}$ & $6.7^{\mathrm{a}}$ & $2.5^{\mathrm{b}}$ & $3.2^{\mathrm{ab}}$ & $3.5^{\mathrm{b}}$ & $3.2^{\mathrm{b}}$ & $3.3^{\mathrm{ab}}$ & $2.1^{\mathrm{ab}}$ & 0.01 \\
\hline Jan & $6.8^{\mathrm{ab}}$ & $6.7^{\mathrm{ab}}$ & $7.5^{\mathrm{a}}$ & $3.7^{\mathrm{b}}$ & $3.3^{\mathrm{b}}$ & $4.0^{\mathrm{b}}$ & $4.2^{\mathrm{b}}$ & $4.4^{\mathrm{b}}$ & $2.6^{\mathrm{b}}$ & 0.001 \\
\hline $\mathrm{Feb}$ & $0.1^{\mathrm{ab}}$ & $0.1^{\mathrm{ab}}$ & $0.1^{\mathrm{a}}$ & $0.1^{\mathrm{ab}}$ & $0.1^{\mathrm{ab}}$ & $0.0^{\mathrm{b}}$ & $0.1^{\mathrm{b}}$ & $0.1^{\mathrm{ab}}$ & $0.0^{\mathrm{ab}}$ & 0.04 \\
\hline Mar & 1.6 & 1.6 & 2.0 & 1.4 & 1.2 & 1.1 & 1.6 & 1.6 & 0.8 & n.s. \\
\hline Apr & 1.5 & 1.5 & 1.5 & 1.4 & 1.2 & 1.2 & 2.0 & 1.6 & 1.1 & n.s. \\
\hline May & 0.0 & 0.0 & 0.0 & 0.0 & 0.0 & 0.0 & 0.1 & 0.0 & 0.0 & n.s. \\
\hline Jun & 1.0 & 1.2 & 1.2 & 1.1 & 0.8 & 0.8 & 1.5 & 1.0 & 1.0 & n.s. \\
\hline Total: & $35^{\mathrm{a}}$ & $33^{\mathrm{a}}$ & $33^{\mathrm{a}}$ & $20^{\mathrm{b}}$ & $19^{\mathrm{ab}}$ & $21^{\mathrm{b}}$ & $23^{\mathrm{b}}$ & $23^{\mathrm{ab}}$ & $16^{\mathrm{ab}}$ & 0.06 \\
\hline \multicolumn{11}{|c|}{ Experiment 2, 2005/2006 (cold winter) } \\
\hline Oct & 0.3 & 0.4 & 0.3 & 0.4 & 0.3 & 0.2 & 0.3 & 0.3 & 0.3 & n.s. \\
\hline Nov & 1.6 & 1.8 & 1.5 & 1.7 & 1.4 & 0.9 & 1.3 & 1.4 & 1.3 & n.s. \\
\hline Dec & 2.6 & 2.8 & 2.9 & 2.6 & 2.2 & 2.1 & 2.4 & 2.4 & 2.7 & n.s. \\
\hline Jan & 1.2 & 1.3 & 1.3 & 1.2 & 1.0 & 0.9 & 1.1 & 1.0 & 1.2 & n.s. \\
\hline $\mathrm{Feb}$ & 0.1 & 0.1 & 0.1 & 0.1 & 0.1 & 0.0 & 0.1 & 0.1 & 0.1 & n.s. \\
\hline Mar & 12.4 & 12.6 & 14.1 & 12.2 & 11.6 & 9.6 & 11.0 & 9.7 & 13.1 & n.s. \\
\hline Apr & 19.6 & 21.0 & 23.2 & 18.1 & 18.0 & 16.3 & 17.5 & 15.6 & 21.3 & n.s. \\
\hline May & 2.8 & 2.9 & 3.5 & 2.0 & 1.9 & 2.3 & 2.4 & 2.4 & 2.9 & n.s. \\
\hline Total: & 41 & 43 & 47 & 38 & 37 & 32 & 36 & 33 & 43 & n.s. \\
\hline
\end{tabular}

Legend: see Table I; n.s.: not significant. Monthly mean values followed by different letters are significantly different at $P<0.05$.

Table IV. Soil mineral N $(0-90 \mathrm{~cm})$ in treatments with and without a winter oilseed rape crop.

\begin{tabular}{lccc}
\hline \multirow{2}{*}{ Treatment } & \multicolumn{3}{c}{ Soil mineral N $\left(\mathrm{kg} \mathrm{N} \mathrm{ha}^{-1}\right)$} \\
Experiment 1, 2004/05 & At sowing & Late autumn & Early spring \\
ABC & 106 & 55 & 1 Apr 05 \\
D & 117 & 28 & 54 \\
EFGHI & 91 & 30 & 48 \\
$P$-value* & n.d. & n.d. & n.d \\
\hline Experiment 2, 2005/06 & 23 Aug 05 & 17 Nov 05 & 12 Apr 06 \\
ABC & 64 & $46^{\mathrm{a}}$ & 53 \\
D & 72 & $34^{\mathrm{b}}$ & 41 \\
EFGHI & 68 & $32^{\mathrm{b}}$ & 50 \\
$P$-value & n.d & 0.006 & 0.55 \\
\hline
\end{tabular}

Legend: see Table I; n.d.: not determined. Mean values within columns and experiments followed by different letters are significantly different at $P<0.05$.

similar concentrations to those without a crop during the mild winter, ranging between $13-40 \mathrm{mg}$ nitrate- $\mathrm{N} \mathrm{L}^{-1}$. The large amounts of mineral $\mathrm{N}$ present in soil at the time of sowing WOR were reduced by November in all treatments (Tab. IV). The $\mathrm{N}$ uptake by the WOR crop was considerable (Tab. V) and the amounts of mineral $\mathrm{N}$ in November were on average 25 and $13 \mathrm{~kg} \mathrm{~N}^{-1}$ smaller than in treatments without a crop during the two experimental years.

Growing a WOR crop compared with no crop after tillage in August reduced leaching in the mild winter of 2004/2005.
This clearly showed the importance of crop $\mathrm{N}$ uptake during autumn in decreasing $\mathrm{N}$ leaching. Fertilising WOR with 60 instead of $30 \mathrm{~kg} \mathrm{~N} \mathrm{ha}^{-1}$ at sowing did not increase $\mathrm{N}$ leaching due to larger crop $\mathrm{N}$ uptake, and soil mineral $\mathrm{N}$ content in late autumn was small at both fertilisation levels (Tabs. IV and V). This indicates that most of the fertiliser $\mathrm{N}$ and soil mineral $\mathrm{N}$ available had been taken up by the crop. The losses of aboveground biomass $\left(\mathrm{kg} \mathrm{N} \mathrm{ha}^{-1}\right)$ during winter were similar at both $\mathrm{N}$ fertilisation levels (Tab. V).

The reason for similar leaching with and without a crop during March and April after the cold winter of 2005/2006 was probably partly due to a dry autumn with low drainage and partly to no soil tillage being carried out in August in treatments without a crop. Furthermore, in November, nitrate concentrations in November were high in soil water (data not shown), probably due to increased $\mathrm{N}$ mineralisation in soil when soil was rewetted again after a dry period (Fig. 1), and remained so until spring since the soil was frozen from December to March. There was a thicker snow cover during a longer period which began to melt in mid-March. This resulted in high overall $\mathrm{N}$ leaching during March and April in all treatments. It is generally believed that cold winters with deeply frozen soils reduce $\mathrm{N}$ leaching, partly due to increased surface runoff during snowmelt reducing water percolation through the soil profile (Gustafson, 1983). Although reduced $\mathrm{N}$ leaching was found in experiment 1 during the cold winter of 2005/2006, the enhanced N losses in March and April seem to contradict the earlier findings. The reason in this case seems to be the high coarse sand content of the subsoil in 
Table V. Aboveground dry matter, $\mathrm{N}$ concentration and $\mathrm{N}$ uptake of winter oilseed rape in treatments D-I and of weeds and volunteers in treatments A-C, in late autumn and early spring.

\begin{tabular}{|c|c|c|c|c|c|c|}
\hline \multirow{2}{*}{$\begin{array}{l}\text { Late autumn } \\
\text { Treatment }\end{array}$} & \multicolumn{6}{|c|}{ Early spring } \\
\hline & $\begin{array}{c}\text { Biomass } \\
\left(\mathrm{kg} \mathrm{DM} \mathrm{ha}^{-1}\right)\end{array}$ & $\begin{array}{c}\text { N uptake } \\
\left(\mathrm{kg} \mathrm{N} \mathrm{ha}^{-1}\right)\end{array}$ & $\begin{array}{l}\mathrm{N} \text { conc. } \\
(\% \text { of } \mathrm{DM})\end{array}$ & $\begin{array}{c}\text { Biomass } \\
\left(\mathrm{kg} \mathrm{DM} \mathrm{ha}^{-1}\right)\end{array}$ & $\begin{array}{c}\mathrm{N} \text { uptake } \\
\left(\mathrm{kg} \mathrm{N} \mathrm{ha}^{-1}\right)\end{array}$ & $\begin{array}{c}\text { N conc. } \\
(\% \text { of } \mathrm{DM})\end{array}$ \\
\hline Experiment 1, 2004/05 & & 5 Nov 04 & & & 30 Mar 05 & \\
\hline $\mathrm{ABC}$ & 192 & $8^{c}$ & 4.0 & & & \\
\hline $\mathrm{D}$ & 1520 & $47^{\mathrm{b}}$ & 3.1 & 509 & 22 & 4.3 \\
\hline EFGHI & 2070 & $74^{\mathrm{a}}$ & 3.6 & 1117 & 51 & 4.6 \\
\hline$P$-value* & & 0.001 & & & 0.06 & \\
\hline Experiment 2, 2005/06 & & 11 Nov 05 & & & & \\
\hline $\mathrm{ABC}$ & 370 & $14^{\mathrm{b}}$ & 3.7 & n.d & n.d. & n.d \\
\hline $\mathrm{D}$ & 1390 & $47^{\mathrm{a}}$ & 3.2 & n.d & n.d. & n.d \\
\hline EFGHI & 1720 & $75^{\mathrm{a}}$ & 4.2 & n.d & n.d. & n.d \\
\hline$P$-value & & 0.006 & & & & \\
\hline
\end{tabular}

Legend: see Table I; DM: dry matter; n.d: not determined. Mean values within columns and experiments followed by different letters are significantly different at $P<0.05$.

combination with the comparatively thick snow cover protecting the soil from freezing more than just superficially. Due to this, excess water must have percolated rapidly through the sand soil layers at snowmelt and thawing.

The lost biomass $\mathrm{N}$ during winter corresponded to the increase in soil mineral $\mathrm{N}$ from late autumn to early spring (in experiment 1), indicating that $\mathrm{N}$ from decaying leaves could have contributed when drainage occurred in March and April after the cold winter. The high $\mathrm{N}$ concentration in the leaves in late autumn indicates that the organic $\mathrm{N}$ could easily have been released during decomposition (Tab. V). Similar amounts of N losses in biomass over winter due to frost have been reported by Dejoux et al. (2000). They concluded that decomposition of the leaves was well synchronised to crop $\mathrm{N}$ uptake during early spring and showed that $40 \%$ of the $\mathrm{N}$ in leaves lost over winter was taken up by the crop again, using a $\mathrm{N}^{15}$ technique in their investigation. However, when high drainage flows occurred in March and April, as after the cold winter in the present study, mineralised $\mathrm{N}$ from leaves could have been partly lost instead of being taken up again by the crop when growth started again after winter.

Our results showed that $\mathrm{N}$ leaching under WOR can be high in spring after a cold winter, if the $\mathrm{N}$ mineralisation rate is high when crop uptake is low in late autumn on a sandy loam soil. In fact, $\mathrm{N}$ leaching was $17 \mathrm{~kg} \mathrm{~N} \mathrm{ha}^{-1}$ higher in the cold winter of 2005/2006 than in the mild winter of 2004/2005, despite lower drainage amounts in the former (130 $\mathrm{mm}$ compared with $214 \mathrm{~mm})$. Thus, it is important to consider measures against leaching from all light-textured soils with high mineralisation potential, not only in regions dominated by wet and mild winters.

\subsection{Yields of winter oilseed rape, peas and spring oats}

The yields of the crops were at normal levels for the region except for oilseed rape in experiment 2, when yields were reduced due to loss of seeds before harvest in an attack by cabbage gall midge (Dasyneura brassicae L). Yields of oats, peas and WOR were on average 4810, 3950 and $3150 \mathrm{~kg} \mathrm{DM} \mathrm{ha}^{-1}$, respectively, in experiment 1 and 5980, 2850 and $1820 \mathrm{~kg} \mathrm{DM}$ $\mathrm{ha}^{-1}$, respectively, in experiment 2. Catch crops undersown in oilseed rape and peas did not affect the yields of the main crops. There were no significant differences in seed yield or crude fat content of oilseed rape fertilised in spring with $\mathrm{N}$ rates of 100,150 and $200 \mathrm{~kg} \mathrm{~N}^{-1}$ in the experiments. The calculated optimum spring $\mathrm{N}$ fertilisation rate was $150 \mathrm{~kg} \mathrm{~N}$ $\mathrm{ha}^{-1}$ (at $3640 \mathrm{~kg} \mathrm{DM} \mathrm{ha}^{-1}$ ) in experiment 1 and $100 \mathrm{~kg} \mathrm{~N} \mathrm{ha}^{-1}$ (at $1850 \mathrm{~kg} \mathrm{DM} \mathrm{ha}^{-1}$ ) in experiment 2 , and agrees with general recommendations for the yields obtained. Application of 30 or $60 \mathrm{~kg} \mathrm{~N} \mathrm{ha}^{-1}$ at sowing of WOR had no effect on yields despite the higher $\mathrm{N}$ uptake of WOR in late autumn and early spring at the highest $\mathrm{N}$ rate.

\subsection{Nitrate leaching after harvest of winter oilseed rape, peas and spring oats}

During autumn and winter with winter wheat, sown after WOR, $\mathrm{N}$ leaching was, on average, $42 \mathrm{~kg} \mathrm{~N} \mathrm{ha}^{-1}$ in the cold winter in experiment 1 (Tab. VI), which was significantly lower than the mild winter in experiment $2\left(58 \mathrm{~kg} \mathrm{~N} \mathrm{ha}^{-1}\right.$, $P=0.001)$. This difference was probably due to the drainage volume being almost doubled in the mild winter compared with the cold winter (Fig. 1), with similar nitrate concentrations in soil water in the experiments (range 10-55 mg nitrate$\mathrm{N} \mathrm{L}^{-1}$; data not shown). $\mathrm{N}$ leaching under winter wheat was 18 and $32 \mathrm{~kg} \mathrm{~N} \mathrm{ha}^{-1}$ greater in the cold and mild winters, respectively, than under WOR in the mild winter. Other studies have also shown that the risk of $\mathrm{N}$ leaching is higher in the drainage period after harvest of WOR than during its growth (Sieling et al., 1997; Sieling and Kage, 2006). The amount of $\mathrm{N}$ leached during autumn and winter after harvest was generally high for Swedish conditions. Similar amounts were found on a sandy soil with and without manure application in southern Sweden, with a maritime climate, where annual leaching was $59-80 \mathrm{~kg} \mathrm{~N} \mathrm{ha}^{-1}$ on average for five years (Torstensson and Aronsson, 2000). 
Table VI. Nitrate leaching ( $\left.\mathrm{kg} \mathrm{NO}_{3}^{-} \mathrm{N} \mathrm{ha}^{-1}\right)$ from July to June (only months with detectable leaching are shown) in two experiments with winter wheat in all treatments (except in $\mathrm{C}$ with spring wheat) subsequent to winter oilseed rape (WOR), peas and oats.

\begin{tabular}{|c|c|c|c|c|c|c|c|c|c|c|}
\hline \multirow{2}{*}{$\begin{array}{l}\text { Treatment } \\
\text { Month }\end{array}$} & $\mathrm{A}$ & $\mathrm{B}$ & $\mathrm{C}$ & $\mathrm{D}$ & $\mathrm{E}$ & $\mathrm{F}$ & $\bar{G}$ & $\mathrm{H}$ & I & \multirow[t]{2}{*}{$P$-value } \\
\hline & & & & & & & & & & \\
\hline \multicolumn{11}{|c|}{ Experiment $1,2005 / 2006$ (cold winter) } \\
\hline Oct & 0.3 & 0.3 & 0.2 & 0.2 & 0.2 & 0.3 & 0.2 & 0.3 & 0.3 & n.s. \\
\hline Nov & 1.2 & 1.4 & 1.3 & 1.2 & 0.9 & 1.3 & 1.0 & 1.4 & 1.5 & n.s. \\
\hline Dec & 2.8 & 2.2 & 2.2 & 2.3 & 1.6 & 2.6 & 2.2 & 3.6 & 3.2 & n.s. \\
\hline Jan & $1.2^{\mathrm{ab}}$ & $1.0^{\mathrm{ab}}$ & $1.2^{\mathrm{ab}}$ & $1.1^{\mathrm{ab}}$ & $0.8^{\mathrm{b}}$ & $1.1^{\mathrm{ab}}$ & $1.0^{\mathrm{ab}}$ & $1.6^{\mathrm{a}}$ & $1.5^{\mathrm{ab}}$ & 0.04 \\
\hline $\mathrm{Feb}$ & 0.1 & 0.1 & 0.1 & 0.1 & 0.0 & 0.1 & 0.0 & 0.1 & 0.1 & n.s. \\
\hline Mar & 11.1 & 11.9 & 17.1 & 11.7 & 9.7 & 9.9 & 9.2 & 17.1 & 15.6 & n.s. \\
\hline Apr & 18.6 & 24.1 & 27.0 & 18.6 & 15.9 & 16.8 & 16.7 & 29.6 & 27.2 & n.s. \\
\hline May & $2.7^{\mathrm{ab}}$ & $3.7^{\mathrm{ab}}$ & $2.2^{\mathrm{ab}}$ & $2.5^{\mathrm{ab}}$ & $2.6^{\mathrm{ab}}$ & $2.0^{\mathrm{b}}$ & $2.4^{\mathrm{ab}}$ & $4.4^{\mathrm{a}}$ & $3.5^{\mathrm{ab}}$ & 0.02 \\
\hline Total: & 38 & 45 & 51 & 38 & 32 & 34 & 33 & 58 & 53 & 0.10 \\
\hline \multicolumn{11}{|c|}{ Experiment 2, 2006/2007 (mild winter) } \\
\hline Aug & $5.7^{\mathrm{a}}$ & $6.0^{\mathrm{a}}$ & $6.4^{\mathrm{a}}$ & $3.4^{\mathrm{ab}}$ & $1.3^{\mathrm{b}}$ & $3.8^{\mathrm{ab}}$ & $4.7^{\mathrm{ab}}$ & $7.9^{\mathrm{a}}$ & $4.8^{\mathrm{ab}}$ & 0.001 \\
\hline Sep & $0.7^{\mathrm{b}}$ & $0.8^{\mathrm{b}}$ & $0.8^{\mathrm{b}}$ & $0.4^{\mathrm{bc}}$ & $0.2^{\mathrm{c}}$ & $0.5^{b c}$ & $0.6^{\mathrm{bc}}$ & $1.0^{\mathrm{a}}$ & $0.6^{\mathrm{bc}}$ & 0.001 \\
\hline Oct & $13.3^{\mathrm{ab}}$ & $15.4^{\mathrm{ab}}$ & $14.5^{\mathrm{ab}}$ & $8.9^{\mathrm{bc}}$ & $3.5^{\mathrm{c}}$ & $11.0^{\mathrm{bc}}$ & $12.8^{\mathrm{bc}}$ & $20.1^{\mathrm{a}}$ & $11.0^{\mathrm{abc}}$ & 0.001 \\
\hline Nov & $14.4^{\mathrm{ab}}$ & $19.9^{\mathrm{a}}$ & $13.0^{\mathrm{ab}}$ & $10.5^{\mathrm{b}}$ & $9.5^{\mathrm{b}}$ & $13.9^{\mathrm{ab}}$ & $16.6^{\mathrm{ab}}$ & $19.5^{\mathrm{a}}$ & $12.9^{\mathrm{ab}}$ & 0.004 \\
\hline Dec & $9.2^{\mathrm{b}}$ & $16.8^{\mathrm{b}}$ & $9.1^{\mathrm{b}}$ & $17.6^{\mathrm{b}}$ & $12.8^{\mathrm{b}}$ & $16.1^{\mathrm{ab}}$ & $19.2^{\mathrm{ab}}$ & $25.8^{\mathrm{a}}$ & $18.3^{\mathrm{ab}}$ & 0.001 \\
\hline Jan & $4.4^{\mathrm{b}}$ & $5.7^{\mathrm{b}}$ & $5.6^{\mathrm{b}}$ & $11.5^{\mathrm{b}}$ & $5.8^{\mathrm{b}}$ & $9.2^{\mathrm{b}}$ & $11.6^{\mathrm{b}}$ & $17.8^{\mathrm{a}}$ & $10.4^{\mathrm{b}}$ & 0.001 \\
\hline Feb & $0.8^{\mathrm{b}}$ & $0.9^{\mathrm{b}}$ & $1.2^{\mathrm{a}}$ & $1.8^{\mathrm{ab}}$ & $1.1^{\mathrm{b}}$ & $1.4^{\mathrm{ab}}$ & $1.8^{\mathrm{ab}}$ & $2.8^{\mathrm{a}}$ & $1.8^{\mathrm{ab}}$ & 0.005 \\
\hline Mar & $2.4^{\mathrm{b}}$ & $3.1^{\mathrm{b}}$ & $4.1^{\mathrm{ab}}$ & $3.8^{\mathrm{ab}}$ & $2.5^{\mathrm{b}}$ & $3.8^{\mathrm{ab}}$ & $4.2^{\mathrm{ab}}$ & $6.6^{\mathrm{b}}$ & $3.8^{\mathrm{ab}}$ & 0.006 \\
\hline Apr & $0.0^{\mathrm{b}}$ & $0.0^{\mathrm{b}}$ & $0.0^{\mathrm{a}}$ & $0.0^{\mathrm{ab}}$ & $0.0^{\mathrm{ab}}$ & $0.0^{\mathrm{ab}}$ & $0.0^{\mathrm{ab}}$ & $0.0^{\mathrm{b}}$ & $0.0^{\mathrm{ab}}$ & 0.005 \\
\hline May & $0.1^{\mathrm{ab}}$ & $0.1^{\mathrm{b}}$ & $0.1^{\mathrm{a}}$ & $0.1^{\mathrm{ab}}$ & $0.1^{\mathrm{ab}}$ & $0.1^{\mathrm{ab}}$ & $0.1^{\mathrm{ab}}$ & $0.1^{\mathrm{a}}$ & $0.1^{\mathrm{ab}}$ & 0.05 \\
\hline Total: & $45^{\mathrm{c}}$ & $63^{b}$ & $48^{\mathrm{bc}}$ & $55^{\mathrm{bc}}$ & $35^{\mathrm{c}}$ & $56^{\mathrm{bc}}$ & $67^{\mathrm{b}}$ & $94^{\mathrm{a}}$ & $59^{\mathrm{bc}}$ & 0.001 \\
\hline
\end{tabular}

Legend: see Table I; n. s.: not significant. Monthly mean values followed by different letters are significantly different at $P<0.05$.

In the cold winter, however, leaching under winter wheat and WOR was more at a similar level compared with during the mild winters where differences were large. Multivariate analysis with results plotted in a PCA demonstrated this clearly by grouping the three different years separately (Fig. 2). The mild winters with WOR and wheat are shown as two groups along a line on the left side in the score plot, whereas the cold winter is on the right side. The variables $(\mathrm{N}$ leaching, nitrate concentration and yield) were very well explained by the first two PC components (80\%). The highest $\mathrm{N}$ leaching in winter wheat in 2006/2007 coincided with leaching from August to February and nitrate concentrations in autumn, whereas the lowest total leaching in WOR in 2004/2005 coincided with summer leaching. The cold winter of 2005/2006, with average high and similar leaching for WOR and winter wheat, is grouped on the right side in the score plot coinciding with $\mathrm{N}$ leaching and concentrations in spring. Consequently, cold winters with a long-lasting snow cover and main drainage in early spring can cause high leaching regardless of growing WOR or winter wheat.

Despite the different weather conditions in the two experiments with wheat, significantly higher average total $\mathrm{N}$ leaching $(P=0.0001)$ was found in winter wheat following WOR fertilised above the optimum spring $\mathrm{N}$ rate at $200 \mathrm{~kg} \mathrm{~N}^{-1}$ compared with after lower $\mathrm{N}$ rates and after oats (Tab. VI, Fig. 2). An increase in $\mathrm{N}$ rate from 150 to $200 \mathrm{~kg} \mathrm{~N}^{-1}$ enhanced $\mathrm{N}$ leaching by $26 \mathrm{~kg} \mathrm{~N} \mathrm{ha}{ }^{-1}$, giving a rate of $0.5 \mathrm{~kg}$ leached $\mathrm{N}$ per $\mathrm{kg}$ fertiliser $\mathrm{N}$ in both experiments (Fig. 3). In experiment 2 the optimum $\mathrm{N}$ rate for WOR was cal- culated to be $100 \mathrm{~kg} \mathrm{~N}^{-1}$. Leaching increased by $11 \mathrm{~kg} \mathrm{~N}$ $\mathrm{ha}^{-1}$ between 100 and $150 \mathrm{~kg} \mathrm{~N} \mathrm{ha}^{-1}$ and corresponded to a rate of $0.2 \mathrm{~kg}$ per $\mathrm{kg}$ fertiliser $\mathrm{N}$, which was the same as between spring $\mathrm{N}$ rates of 0 and $100 \mathrm{~kg} \mathrm{~N}^{-1}$. This indicates that the optimum $\mathrm{N}$ rate may have been underestimated in that year, possibly due to the loss of seeds caused by midge attack. In the cold winter, $\mathrm{N}$ leaching for $\mathrm{N}$ rates below the optimum remained at a constant level.

Soil mineral $\mathrm{N}$ at maturity of WOR and in late autumn increased with higher fertilisation $\mathrm{N}$ rates in both experiments (Tab. VII). The relationship could be described by a linear function with a slope of 0.3 (Fig. 3). On average for the two experiments, significant differences $(P=0.0001)$ were found between all $\mathrm{N}$ rates at maturity except between 100 and $150 \mathrm{~kg} \mathrm{~N} \mathrm{ha}^{-1}$, and these differences remained during autumn $(P=0.02)$. In a similar way, Beaudoin et al. (2005) described the relationship between soil mineral $\mathrm{N}$ at harvest of WOR and calculated excess fertiliser $\mathrm{N}$ with a linear function with a slope of 0.4 , while for $\mathrm{N}$ rates below the optimum the data were fitted to a plateau. The relationship between $\mathrm{N}$ rates and leaching has been described in several studies and the conclusion that the slope of the curve is smaller at rates below optimum fertilisation levels than above the optimum seems reliable (e.g. Bergström and Brink, 1986; Simmelsgaard and Djurhuus, 1998).

The results show the importance of focusing on accurately adjusting the spring $\mathrm{N}$ rate to crop requirements in order to reduce leaching after winter oilseed rape under both mild and cold winter conditions. Considering overwintering soil 

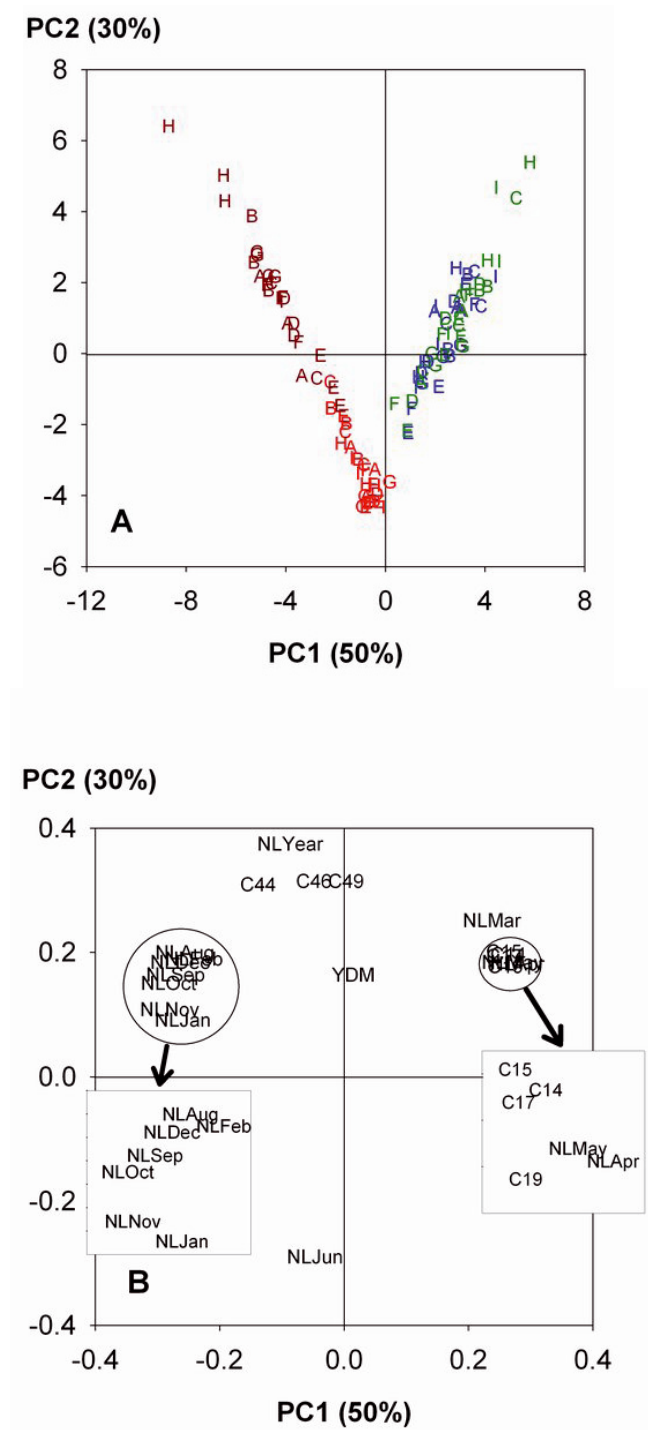

Figure 2. Score plot (A) and loading plot (B) for the first two principal components based on treatments A-I, N leaching, nitrate concentration and yield in experiments 1 (red and green) and 2 (green and brown). Legend: see Table I; red (lower left quadrant): winter oilseed rape 2004/05; green (upper right quadrant): wheat 2005/06; blue: winter oilseed rape 2005/06; brown (upper left quadrant): winter wheat 2006/07; rapeNL: amount N leached for indicated month; NLYear; $\mathrm{N}$ leaching for the total drainage period; $\mathrm{C}$ : measured nitrate concentration for indicated week number; YDM: dry matter yield.

mineral $\mathrm{N}$ at spring fertilisation of WOR has little relevance in Sweden, since the amounts generally are small (Delin and Lindén, 2002). However, increased $\mathrm{N}$ uptake in autumn by winter oilseed rape has been found to have a negative correlation with optimum $\mathrm{N}$ rate in spring (Henke et al., 2009). Thus, considering the $\mathrm{N}$ uptake in late autumn when calculating the spring $\mathrm{N}$ rate is one way to optimise the latter. Promoting more $\mathrm{N}$ uptake during autumn by early sowing date and fertilisation is another possibility, but high $\mathrm{N}$ rates at sowing cannot be recommended with respect to the risk of $\mathrm{N}$ leaching.

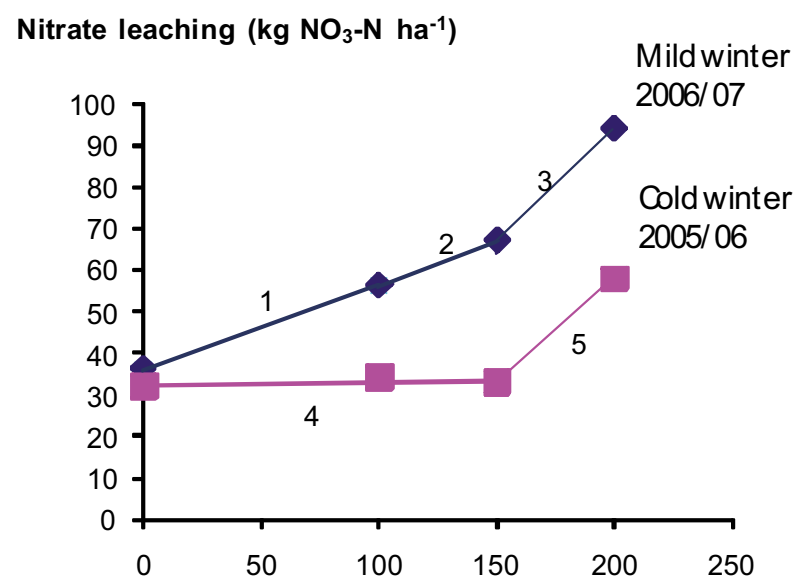

A

Spring $\mathbf{N}$ rate to winter oilseed rape $\left(\mathrm{kg} \mathrm{N} \mathrm{ha}^{-1}\right)$

\section{Soil mineral $\mathbf{N}$ in late autumn (kg $\mathbf{N ~ h a - 1 ) ~}$}

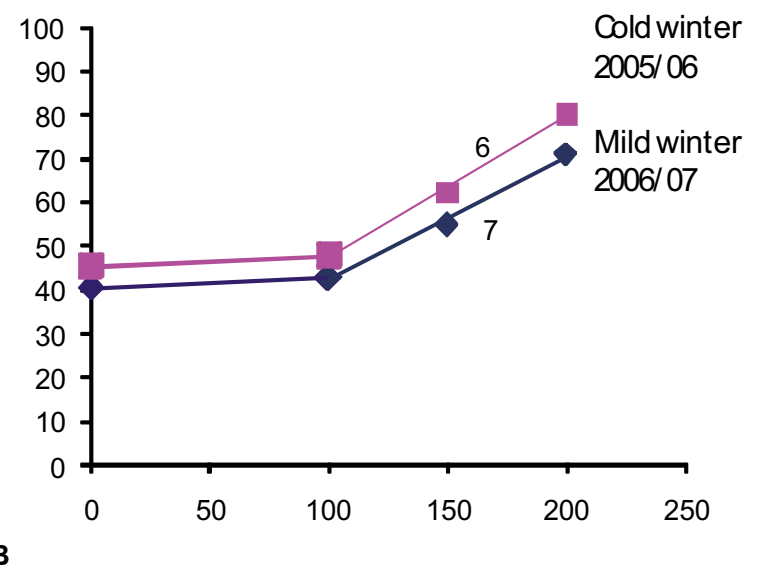

Spring $\mathbf{N}$ rate to winter oilseed rape $\left(\mathrm{kg} \mathrm{N} \mathrm{ha}^{-1}\right)$

Figure 3. Relationship between spring $\mathrm{N}$ rate to winter oilseed rape and (A) $\mathrm{N}$ leaching during autumn and winter; and (B) soil mineral $\mathrm{N}$ in late autumn in the two experiments on a sandy loam soil. Equations for slope $1: \mathrm{y}=0.2 \mathrm{x}+36$; slope $2: \mathrm{y}=0.2 \mathrm{x}+34$; slope $3: \mathrm{y}=0.5 \mathrm{x}-$ 13; slope 4: $y=0 x+32$; slope $5: y=0.5 x-42$; slope $6: y=0.3 x+$ 15; slope 7: $y=0.3 x+14$.

Perennial ryegrass as an undersown catch crop grown after harvest of oilseed rape (at optimum $\mathrm{N}$ rate) until midSeptember, when wheat was established, reduced leaching $(P=0.04)$ by $20 \%\left(12 \mathrm{~kg} \mathrm{~N} \mathrm{ha}^{-1}\right)$ in the mild winter (Tab. VI). The increased $\mathrm{N}$ leaching $(P=0.05)$ of $22 \mathrm{~kg} \mathrm{~N}^{-1}$ after oilseed rape fertilised at this level was thus reduced by half compared with after oats. The $\mathrm{N}$ uptake of the ryegrass catch crop until mid-September after oilseed rape was $19 \mathrm{~kg} \mathrm{~N} \mathrm{ha}^{-1}$ and the $\mathrm{N}$ uptake by the winter wheat until November was $9 \mathrm{~kg} \mathrm{~N} \mathrm{ha}^{-1}$ (data not shown). Soil mineral $\mathrm{N}$ in late autumn was not affected, indicating that the $\mathrm{N}$ uptake by the catch crop 
Table VII. Soil mineral N (0-90 cm) on four occasions from harvest of crop 1 (winter oilseed rape (WOR), peas and oats) until harvest of subsequent winter and spring wheat, unfertilised and fertilised with $100 \mathrm{~kg} \mathrm{~N} \mathrm{ha}^{-1}$. Grain yield (15\% moisture) and aboveground $\mathrm{N}$ uptake of spring and winter wheat (crop 2) in treatments A-I.

\begin{tabular}{|c|c|c|c|c|c|c|c|c|}
\hline \multirow{2}{*}{$\begin{array}{l}\text { Treatment } \\
\text { and crop }\end{array}$} & \multicolumn{5}{|c|}{ Soil mineral $\mathrm{N}\left(\mathrm{kg} \mathrm{N} \mathrm{ha}^{-1}\right)$} & \multicolumn{3}{|c|}{ Yield of wheat } \\
\hline & Harvest of crop 1 & Late autumn & Early spring & Harv & ff wheat & $\left(\mathrm{kg} \mathrm{ha}^{-1}\right)$ & $\mathrm{N}$ uptake $\left(\mathrm{kg} \mathrm{N} \mathrm{ha}^{-1}\right)$ & $\left(\mathrm{kg} \mathrm{ha}^{-1}\right)$ \\
\hline \multicolumn{2}{|c|}{ Experiment 1, 2005/06 } & & & $0 \mathrm{~N}$ & $100 \mathrm{~N}$ & $0 \mathrm{~N}$ & $0 \mathrm{~N}$ & $100 \mathrm{~N}$ \\
\hline & 8-11 Aug & $18 \mathrm{Nov}$ & $21 \mathrm{Apr}$ & \multicolumn{2}{|c|}{7 Aug } & & & \\
\hline A & $43^{\mathrm{bc}}$ & 57 & 49 & 35 & $35^{\mathrm{b}}$ & 4120 & 61 & 6310 \\
\hline B & $59^{\mathrm{bc}}$ & 54 & 52 & 29 & $41^{\mathrm{ab}}$ & 4470 & 53 & 6650 \\
\hline $\mathrm{C}$ & $42^{\mathrm{bc}}$ & 38 & 53 & 36 & $62^{\mathrm{a}}$ & 3900 & 72 & 5080 \\
\hline $\mathrm{D}$ & $64^{\mathrm{b}}$ & 59 & 51 & 38 & $37^{\mathrm{b}}$ & 4390 & 59 & 7390 \\
\hline $\mathrm{E}$ & $35^{\mathrm{c}}$ & 45 & 61 & 32 & $39^{\mathrm{ab}}$ & 4540 & 56 & 7480 \\
\hline $\mathrm{F}$ & $54^{\mathrm{b}}$ & 48 & 49 & 31 & $38^{\mathrm{b}}$ & 4470 & 57 & 6950 \\
\hline G & $70^{\mathrm{b}}$ & 62 & 60 & 36 & $37^{\mathrm{b}}$ & 4650 & 63 & 7290 \\
\hline $\mathrm{H}$ & $103^{\mathrm{a}}$ & 80 & 62 & 35 & $43^{\mathrm{ab}}$ & 4830 & 69 & 6870 \\
\hline I & $79^{\mathrm{ab}}$ & 86 & 71 & 44 & $52^{\mathrm{ab}}$ & 4360 & 65 & 6520 \\
\hline$P$-value* & 0.001 & n.d. & n.s. & n.s. & 0.02 & n.s. & n.s. & n.s. \\
\hline \multicolumn{9}{|c|}{ Experiment 2, 2006/07 } \\
\hline & 4 Aug & $6 \mathrm{Nov}$ & $28 \mathrm{Mar}$ & \multicolumn{2}{|c|}{$30 \mathrm{Jul}$} & & & \\
\hline A & $57^{\mathrm{ab}}$ & $47^{\mathrm{b}}$ & 32 & 20 & 21 & $3280^{\mathrm{b}}$ & $79^{\mathrm{a}}$ & $6540^{\mathrm{a}}$ \\
\hline B & $58^{\mathrm{ab}}$ & $47^{\mathrm{b}}$ & 44 & 17 & 17 & $3210^{\mathrm{b}}$ & $65^{\mathrm{b}}$ & $6860^{\mathrm{a}}$ \\
\hline $\mathrm{C}$ & $45^{\mathrm{ab}}$ & $30^{c}$ & 42 & 19 & 21 & $3230^{\mathrm{b}}$ & $90^{\mathrm{a}}$ & $4040^{\mathrm{b}}$ \\
\hline $\mathrm{D}$ & $60^{\mathrm{ab}}$ & $56^{\mathrm{ac}}$ & 26 & 21 & 19 & $3990^{\mathrm{a}}$ & $79^{a}$ & $7030^{\mathrm{a}}$ \\
\hline $\mathrm{E}$ & $25^{\mathrm{b}}$ & $40^{\mathrm{bc}}$ & 25 & 18 & 18 & $3720^{\mathrm{ab}}$ & $71^{\mathrm{b}}$ & $7070^{\mathrm{a}}$ \\
\hline F & $32^{\mathrm{ab}}$ & $43^{\mathrm{bc}}$ & 31 & 18 & 17 & $3960^{\mathrm{a}}$ & $76^{\mathrm{a}}$ & $6730^{a}$ \\
\hline G & $52^{\mathrm{ab}}$ & $55^{\mathrm{ab}}$ & 27 & 19 & 19 & $3940^{\mathrm{a}}$ & $73^{b}$ & $6720^{\mathrm{a}}$ \\
\hline $\mathrm{H}$ & $79^{a}$ & $71^{\mathrm{a}}$ & 29 & 19 & 18 & $3860^{\mathrm{ab}}$ & $68^{\mathrm{b}}$ & $6580^{\mathrm{a}}$ \\
\hline I & $45^{\mathrm{ab}}$ & $53^{\mathrm{b}}$ & 31 & 20 & 20 & $3750^{\mathrm{ab}}$ & $79^{a}$ & $6660^{\mathrm{a}}$ \\
\hline$P$-value & 0.01 & 0.001 & n.s. & n.s. & n.s. & 0.009 & 0.002 & 0.001 \\
\hline
\end{tabular}

Legend: see Table V; n.s.: not significant; n.d.: not determined, $\mathrm{dd}=$ direct-drilled winter wheat. Means followed by different letters are significantly different at $P<0.05, P$-values are calculated for each trial and occasion.

was not enough to have an impact on soil mineral $\mathrm{N}$ throughout the autumn (Tab. VII). In the cold winter $\mathrm{N}$ leaching was not affected by the catch crops, mainly due to no drainage occurring until early spring.

The results show that it is possible to reduce $\mathrm{N}$ leaching after oilseed rape followed by winter wheat when the catch crop is undersown in the rapeseed in early spring and allowed to grow until winter wheat is sown. A catch crop undersown in spring has the advantage of being capable of taking up unused soil mineral $\mathrm{N}$ directly from harvest of the oilseed rape, whereas a catch crop sown after harvest would have less or no effect. This is especially important in northerly regions such as Sweden where the period between harvest of oilseed rape (August) and sowing of winter wheat (September) is short.

Direct drilling of winter wheat in September after oilseed rape (at the $150 \mathrm{~kg} \mathrm{ha}^{-1} \mathrm{~N}$ rate) did not significantly reduce leaching compared with conventional sowing of winter wheat after oilseed rape, although there was a tendency $(P=0.10)$ for leaching to be $12 \%$ lower $\left(8 \mathrm{~kg} \mathrm{~N} \mathrm{ha}^{-1}\right)$ in the mild winter. Soil mineral $\mathrm{N}$ in direct-drilled plots in late autumn before the mild winter was the same as in the other treatments with winter wheat, indicating that direct drilling stimulated soil $\mathrm{N}$ mineralisation as much. The reason for this may be that the direct drill used was equipped with a cultivating toolbar and also had powerful seed coulters, giving a soil-cultivating effect by the coulters themselves. Direct drilling in Sweden is mainly performed in this way today. The results from the mild winter agree with findings by Constantin et al. (2010) showing that no tillage decreased leaching by $6 \mathrm{~kg} \mathrm{~N} \mathrm{ha}^{-1} \mathrm{yr}^{-1}$ compared with conventional tillage, which was much less than the reduction found with catch crops.

Comparing the treatments with peas and oats, $\mathrm{N}$ leaching was only higher (by $18 \mathrm{~kg} \mathrm{~N} \mathrm{ha}^{-1} ; P=0.02$ ) after the pea crop than after oats in the mild winter (Tab. VI). This level of leaching was the same as after oilseed rape fertilised around the optimum (between 100 and $150 \mathrm{~kg} \mathrm{~N} \mathrm{ha}^{-1}$ ). Growing an undersown catch crop until November after harvest of the peas reduced $\mathrm{N}$ leaching by $24 \%\left(14 \mathrm{~kg} \mathrm{~N} \mathrm{ha}^{-1} ; P=0.05\right)$ during this winter to the same level as after oats, but during the cold winter there was no reduction. Due to the $\mathrm{N}$ uptake of $30 \mathrm{~kg} \mathrm{~N}$ $\mathrm{ha}^{-1}$ by the catch crop during autumn (data not shown), soil mineral $\mathrm{N}$ in late autumn was decreased $(P=0.02)$ by $17 \mathrm{~kg} \mathrm{~N}$ $\mathrm{ha}^{-1}$ compared with peas without a catch crop (Tab. VII). N uptake of winter wheat was only $9 \mathrm{~kg} \mathrm{~N} \mathrm{ha}^{-1}$ during the same period (data not shown).

Torstensson and Aronsson (2000) reported a 35-60\% reduction in $\mathrm{N}$ leaching for an undersown ryegrass catch crop grown until early spring after spring cereals (with and without manure application) compared with soil ploughed in September without a catch crop. In the present study $\mathrm{N}$ 
leaching was reduced by $20-24 \%$ when ryegrass was grown after winter oilseed rape and peas during autumn, until midSeptember and early November (late autumn), respectively. Our results show that an undersown ryegrass catch crop in peas and oilseed rape, as in spring-sown cereal crops, has great potential to reduce $\mathrm{N}$ leaching without reducing the yield of the following wheat crop.

\subsection{Yields of wheat}

There was no increase in $\mathrm{N}$ uptake of winter wheat grown after WOR or peas compared with after oats in the experiments (Tab. VII). Yields of winter wheat after oilseed rape $\left(150 \mathrm{~kg} \mathrm{ha}^{-1}\right)$ and after peas were not significantly higher than after oats, although yields were 1000 and $200 \mathrm{~kg} \mathrm{ha}^{-1}$ higher after WOR (experiments 1 and 2, respectively) and $340 \mathrm{~kg} \mathrm{ha}^{-1}$ higher after peas in both experiments. Different $\mathrm{N}$ fertilisation rates of winter oilseed rape had no effect on winter wheat yields or $\mathrm{N}$ uptake, nor had catch crops after oilseed rape or peas in the two experiments. There were no significant differences between yield of direct-drilled winter wheat and conventionally drilled wheat in the experiments, even though the yield was $800 \mathrm{~kg} \mathrm{ha}^{-1}$ lower $(P=0.10)$ in experiment 1 , where wheat had poorly established. This partly contradicts Engström and Lindén (2009), who reported increased yields and $\mathrm{N}$ uptake in winter wheat in southern Sweden after both winter oilseed rape and peas compared with after oats (at the same site). The generally high soil $\mathrm{N}$ mineralisation and $\mathrm{N}$ leaching at the present study site may have masked the residual $\mathrm{N}$ effect of the previous crops or a high variability between the plots may have blurred potential differences.

\section{CONCLUSION}

Our results show that there are risks of high $\mathrm{N}$ leaching in early spring after a cold winter with a long-lasting snow cover and obviously only superficially frozen soil. Subsequent snowmelt can give rise to abundant spring drainage, resulting in $\mathrm{N}$ leaching amounts similar to those in mild winters. However, the results indicate that measures for reducing $\mathrm{N}$ leaching are important independently of the current winter conditions (mild or cold winters) and the temporal drainage and leaching patterns. Optimising the spring $\mathrm{N}$ rate for WOR was the most effective measure to reduce the risk of $\mathrm{N}$ leaching in both mild and cold winters. Perennial rye grass as a catch crop undersown in spring showed a good potential to reduce leaching after optimally fertilised WOR and peas in mild winters, despite growing only until mid-September after WOR, when winter wheat was sown. Direct drilling of winter wheat after WOR had no effect on leaching and can thus not be recommended.

Acknowledgements: We wish to thank the Swedish Farmers' Foundation for Agricultural Research, the Swedish Foundation for Oilseed Research and the Foundation for Plant Nutrition Research for funding this work.

\section{REFERENCES}

Beaudoin N., Saad J.K., Van Laethem C., Machet J.M., Maucorps J., Mary B. (2005) Nitrate leaching in intensive agriculture in Northern France: Effect of farming practices, soils and crop rotations, Agric. Ecosyst. Environ. 111, 292-310.

Bergström L., Brink N. (1986) Effects of differentiated applications of fertilizer $\mathrm{N}$ on leaching losses and distribution of organic $\mathrm{N}$ in the soil, Plant Soil 93, 333-345.

Biärsjö J., Nilsson B. (2007) N fertilisation to winter oilseed rape (Kväve till höstraps), in: Gruvaeus I. (Ed.), Försöksrapport 2007 för Mellansvenska försökssamarbetet och Svensk raps, Sweden, pp. $98-100$.

Christen O., Sieling K., Hanus H. (1992) The effect of different preceding crops on the development, growth and yield of winter wheat, Eur. J. Agron. 1, 21-28.

Constantin J., Mary B., Laurent F., Aubrion G., Fontaine A., Kerveillant P., Beaudoin N. (2010) Effects of catch crops, no till and reduced nitrogen fertilization on nitrogen leaching and balance in three longterm experiments, Agric. Ecosyst. Environ. 135, 268-278.

Davies D.B., Garwood T.W.D., Rochford A.D.H. (1996) Factors affecting nitrate leaching from a calcareous loam in East Anglia, J. Agric. Sci. $126,75-86$.

Dejoux J.F., Recous S., Meynard J.M., Trinsoutrot I., Leterme P. (2000) The fate of nitrogen from winter-frozen rapeseed leaves: mineralization, fluxes to the environment and uptake by rapeseed crop in spring, Plant Soil 218, 257-272.

Delin S., Lindén B. (2002) Relations between net nitrogen mineralization and soil characteristics within an arable field, Eur. J. Agron. 28, $362-370$.

Djurhuus J. (1990) Sammenligning af nitrat i jordvand udtaget med sugkopper og ekstrahert fra jordprover (A comparison of soil water nitrate determined by coring and solution extraction techniques), Tidskrift for Planteavl 94, 487-495.

Djurhuus J., Olsen P. (1997) Nitrate leaching after cut grass/clover leys as affected by time of ploughing, Soil Use Manage. 13, 61-67.

Engström L., Lindén B. (2009) Importance of soil mineral N in early spring and subsequent net $\mathrm{N}$ mineralisation for winter wheat following winter oilseed rape and peas in a milder climate, Acta Agr. Scand. 59, 402-413.

Gustafson A. (1983) Leaching and nitrate from arable land into groundwater in Sweden, Environ. Geol. 5, 65-71.

Henke J., Bottcher U., Neukam D., Sieling K., Kage H. (2008) Evaluation of different agronomic strategies to reduce nitrate leaching after winter oilseed rape (Brassica napus L.) using a simulation model, Nutr. Cycl. Agroecosyst. 82, 299-314.

Henke J., Sieling K., Sauermann W., Kage H. (2009) Analysing soil and canopy factors affecting optimum nitrogen fertilization rates of oilseed rape (Brassica napus L.), J. Agric. Sci. 147, 1-8.

Jensen E.S. (1987) Seasonal Patterns of Growth and Nitrogen-Fixation in Field-Grown Pea, Plant Soil 101, 29-37.

Jensen E.S., Haahr V. (1990) The effect of pea cultivation on succeeding winter cereals and winter oilseed rape nitrogen nutrition. Appl. Agr. Res. 5, 102-107.

Knudsen L., Birkmose T., Hansen O.M., Ostergaard H.S., Horfarter R., Thomsen K.K., Thomsen A., Berntsen J. (2002) Godskning og kalkning, Oversigt over landsforsogene Forsog og undersogelser i 
de landokonomiske foreninger 2002. Landbrukets rådgivningscenter, Århus, Danmark, pp. 158-210.

Møller Hansen E., Djurhuus J. (1997) Nitrate leaching as influenced by soil tillage and catch crop, Soil Tillage Res. 41, 203-219.

Mulvaney R.L. (1996) Nitrogen-inorganic forms, in: Sparks D.L., Page A.L., Helmke P.A., Leoppert R.H., Soltanpouar P.N., Tabatabai M.A., Johnson C.T., Sumner M.E. (Eds.), Methods of soil Analysis, Part 3-Chemical methods Soil Science, Society of America Book series, Nr 5, Madison, Wisconsin, USA, pp. 1123-1174.

Razoux Schultz J.E. (1972) Undersogelser af vinterrapsens (Brassica napus L.) Torstofproduktion og naeringsstofoptagelser, Tidskrift for Planteavl 76, 415-435.

Ryan M.H., Kirkegaard J.A., Angus J.F. (2006) Brassica crops stimulate soil mineral N accumulation, Aust. J. Soil Res. 44, 367-377.

Shepard M.A., Sylvester-Bradley R. (1996) Effect of nitrogen fertilizer applied to winter oilseed rape (Brassica napus L.) on soil mineral nitrogen after harvest and on the respons of a succeeding crop of winter wheat to nitrogen fertilizer, J. Agric. Sci., Cambridge 126, 63-74.

Sieling K., Gunther-Borstel O., Hanus H. (1997) Effect of slurry application and mineral nitrogen fertilization on $\mathrm{N}$ leaching in different crop combinations, J. Agric. Sci. 128, 79-86.
Sieling K., Gunther-Borstel O., Teebken T., Hanus H. (1999) Soil mineral $\mathrm{N}$ and $\mathrm{N}$ net mineralization during autumn and winter under an oilseed rape - winter wheat - winter barley rotation in different crop management systems, J. Agric. Sci. 132, 127-137.

Sieling K., Kage H. (2006) N balance as an indicator of N leaching in an oilseed rape - winter wheat - winter barley rotation, Agric. Ecosyst. Environ. 115, 261-269.

Simmelsgaard S.E., Djurhuus J. (1998) An empirical model for estimating nitrate leaching as affected by crop type and the long-term $\mathrm{N}$ fertiliser rate, Soil Use Manage. 14, 37-43.

Stenberg M., Aronsson H., Linden B., Rydberg T., Gustafson A. (1999) Soil mineral nitrogen and nitrate leaching losses in soil tillage systems combined with a catch crop, Soil Tillage Res. 50, 115-125.

Torstensson G., Aronsson H. (2000) Nitrogen leaching and crop availability in manured catch crop systems in Sweden, Nutr. Cycl. Agroecosyst. 56, 139-152.

Wallgren B., Lindén B. (1994) Effects of catch crops and ploughing times on soil mineral nitrogen, Swedish J. Agric. Res. 24, 67-75.

Wold S., Esbensen K., Geladi P. (1987), Principal component analysis, Chemometrics and Intelligent Laboratory Systems 2, 37-52. 